\title{
PROBLEMATIKA KEMISKINAN \\ DAN OPTIMALISASI FUNGSI ZAKAT
}

\author{
Ahmad Fathoni \\ UIN Sunan Gunung Djati Bandung \\ Jl. Raya Cipadung No. 105 Ujung Berung Bandung \\ Email: fathoniahmad36@yahoo.com.
}

\begin{abstract}
Abstrak
Kemiskinan merupakan salah satu masalah mendasar yang dihadapi oleh umat Islam di Indonesia. Fenomena tersebut secara tidak langsung dapat membahayakan kekokohan akidah dan keimanan seseorang. Zakat, infaq dan sadaqah sebagai instrumen dalam pengentasan kemiskinan, tidak hanya menjadi persoalan pribadi, melainkan menjadi persoalan bersama. Peran BAZ dan LAZ yang diamanatkan oleh UU 38 Tahun 1999 tentang Pengelolaan Zakat harus dioptimalkan, karena pengentasan kemiskinan tidak hanya cukup dengan regulasi saja, tetapi harus ada sosialisasi serta pengelolaan dan pendayagunaan yang amanah, professional yang didukung dengan legalitas hukum yang kuat. Semua aspek ini pada akhirnya bisa mewujudkan kesejahteraan masyarakat. Tulisan ini mencoba melakukan telaah singkat tentang pengentasan kemiskinan melalui pendayagunaan zakat di Indonesia. Agar tujuannya tercapai, maka campur tangan pemerintah dalam pengelolaan zakat merupakan keharusan.
\end{abstract}

Kata kunci: Pengentasan Kemiskinan, Optimalisasi Zakat, Fungsionalisasi Lembaga Zakat, UU. No. 38/1999 tentang pengelolaan zakat

\begin{abstract}
Poverty is one of the fundamental problems faced by Muslims in Indonesia. It could indirectly decline the quality of Muslims' beliefs and faith. Zakat, infaq, and sadaqah are the instruments of abolishing poverty, which are not only regarded as a personal matter, but also as a communal religious responsibility. The roles of governmental zakat collector body (BAZ) and non-governmental zakat collector agents (LAZ), which are mandated by the law No. 38/1999 on zakat administration, should be optimized, because eradicating poverty is not only by legal instruments but it should also involve professional and accountable managerial skills supported by a strong legal role. These aspects could eventually bring the social prosperity into reality. This paper tries to elaborate briefly pulling out the poverty by means of zakat in Indonesia. This paper also believes that in order to achieve its goal, zakat should be administered by the government.
\end{abstract}

Keywords: Poverty eradication, optimizing zakat, functionalizing zakat agency, the Law No. 38/1999 on zakat management.

A. Pendahuluan.

Salah satu masalah mendasar yang hingga kini dihadapi oleh bangsa Indonesia adalah masalah kemiskinan. ${ }^{1}$ Fenomena kemiskinan adalah fenomena yang sangat akrab dengan kehidupan masyarakat Islam, khususnya di Indonesia. Kemiskinan di Indonesia, merupakan hal yang sangat ironi, mengingat Indonesia adalah sebuah 
negara yang dikaruniai kekayaan alam yang luar biasa hebatnya.

Problematika kemiskinan memang telah ada sejak dahulu. Pada masa lalu umumnya masyarakat menjadi miskin bukan karena kurang pangan, tetapi miskin dalam bentuk minimnya kemudahan atau materi, tidak menikmati fasilitas pendidikan, pelayanan kesehatan, dan kemudahan-kemudahan lainnya yang tersedia pada zaman modern.

Hamdar Arraiyyah ${ }^{2}$ menilai, bahwa kemiskinan bukanlah sesuatu yang terwujud sendiri, terlepas dari aspekaspek lainnya, tetapi terwujud sebagai hasil interaksi antara berbagai aspek yang ada dalam kehidupan manusia. Karenanya akibat dari ketidakmampuan di bidang material, orang miskin mengalami kesulitan untuk memenuhi kebutuhan gizinya, memperoleh pendidikan, modal kerja, dan sejumlah kebutuhan utama lainnya. Akibat lain yang mungkin timbul di antara mereka, antara lain, kurangnya harga diri, moralitas yang rendah, dan kurangnya kesadaran beragama.

Ilmuwan sosial berpandangan bahwa kemiskinan adalah masalah yang kronis dan kompleks. Komplesitas masalah yang ditimbulkan dari kemiskinan, dalam penilaian Muhammad Ja'far Hafsah ${ }^{3}$ bersifat menyebar (multiplier effects), terhadap tatanan kemasyarakatan secara menyeluruh. Sejumlah konflik yang terjadi di tanah air sepanjang krisis ekonomi, misalnya menunjukkan bahwa persoalan ketahanan ekonomi yang ditampilkan oleh rendahnya daya beli masyarakat saja, tetapi juga mempengaruhi ketahanan sosial masyarakat dan ketahanan nasional. Sejumlah hasil kajian menunjukkan bahwa kemiskinan juga merupakan muara dari masalah sosial lainnya. Masalah anak jalanan, perlakuan salah terhadap anak (child abuse), kekerasan dalam rumah tangga (KDRT), rumah kumuh, kejahatan, alkoholisme, kebodohan, dan pengangguran yang erat sekali hubungannya dengan kemiskinan. Didin Hafiddhuddin ${ }^{4}$ juga menilai, bahwa kemiskinan menyebabkan terjadinya proses perubahan budaya bangsa yang sangat signifikan dari bangsa yang berbudaya ramah, suka bergotong royong, dan saling toleransi menjadi bangsa yang hedonis, kasar, pemarah, dan melupakan nilai-nilai kemanusiaan.

Lily Zakiyah Munir ${ }^{5}$ menyoroti bahwa kemiskinan dapat menjadi penyakit yang membahayakan akidah atau keimanan. Orang miskin yang hidup di lingkungan orang kaya yang tidak peduli dengannya, bisa jadi memiliki kecenderungan untuk "memprotes" Tuhan dalam hatinya. Apalagi kalau mereka harus membanting tulang bekerja keras, namun nasibnya tidak berubah juga. Sementara si kaya dengan santai dan mudahnya dapat menumpuk kekayaan. Keadaan seperti itu, dapat memicu keraguan dan pertanyaan atas kebijaksanaan dan keadilan Tuhan dalam distribusi harta kepada umat manusia. Sikap ragu terhadap kehendak Allah, apalagi jika terjadi terus menerus, dapat memperlemah keimanan seseorang dan akan berbahaya terhadap akidah. Efek lain dari kemiskinan bukan hanya mengakibatkan pendangkalan akidah, melainkan dapat mengarahkan kepada kekufuran. Keadaan serba kekurangan, tangisan anak yang kelaparan, serta terpinggirkan dari berbagai fasilitas yang menjadi hak dapat melunturkan iman seseorang.

Kemiskinan membuat orang tidak memiliki kemampuan untuk memenuhi kebutuhan gizi yang cukup, (akses) pendidikan yang semestinya dan penyediaan kebutuhan lain secara laik. Akibatnya, orang yang miskin cenderung berpendidikan rendah, kurang gizi dan hidup dalam keterbatasan. Pendidikan yang rendah membuat kualitas sumberdaya yang dimilikinya juga rendah. Jadi, miskin harta membawa dampak pada miskin keahlian dan pada akhirnya miskin produktivitas. ${ }^{6}$

Islam melalui ajaran pokoknya, baik yang tertuang dalam al-Qur'an maupun Hadis, menganjurkan umatnya untuk menjadi orang kaya dan menjadikan kemiskinan sebagai musuh bersama yang harus di hindari. Oleh karena itu, satu-satunya jalan untuk 
mengubah hal itu adalah dengan memotong mata rantai kemiskinan. Model yang ditawarkan oleh Islam, salah satunya adalah zakat.

Tulisan ini mencoba melakukan telaah singkat tentang pengentasan kemiskinan melalui pendayagunaan zakat di Indonesia. Sebagai sebuah artikel, tentu saja tulisan ini tidak menjanjikan suatu eksplorasi yang mendalam dan komprehensif.

\section{B. Pengertian Normatif tentang Miskin dan Zakat.}

Pengertian tentang kemiskinan sangat beragam, mulai dari pengertian yang sangat sederhana, yaitu ketidakmampuan memenuhi kebutuhan konsumsi dasar dan memperbaiki keadaan, kurangnya kesempatan berusaha, hingga pengertian yang amat luas yang terkait dengan aspek-aspek sosial dan moral.

Dalam Kamus Besar Bahasa Indonesia, ${ }^{7}$ kemiskinan tersusun dari akar kata miskin dengan awalan ke dan akhiran an yang memiliki persamaan dengan kefakiran yang tersusun dari asal kata fakir dengan awalan ke dan akhiran an. Dua kata " fakir dan miskin " mempunyai arti yang berbeda, fakir mempunyai dua pengetian; yaitu 1) orang yang sangat kekurangan; orang yang terlalu miskin. 2) orang yang sengaja membuat dirinya menderita kekurangan untuk mencapai kesempurnaan batin. Sedangkan miskin juga mempunyai pengertian; tidak berharta benda, serba kekurangan, berpenghasilan rendah.

BKKBN memberikan pengertian kemiskinan dengan menggunakan indikator kualitatif, sebagai berikut: 1) makan kurang 2 kali per hari, 2) sebagian besar lantai dari tanah, 3) tidak mempunyai pakaian yang berbeda untuk beragam aktivitas, 4) makan daging/telur minimal sekali per minggu, 5) membeli baju baru minimal sekali per tahun dan 6) luas lantai rumah rata-rata kurang $8 \mathrm{~m}^{2}$ per orang.
Sementara dari perspektif agama, kemiskinan juga didefinisikan beragam. Hal ini karena terdapat dua kata yang sering disebutkan secara bergandengan, yaitu kata fakir dan kata miskin dengan pengertian orang yang sangat kekurangan. al-Qur'an menyebut orang yang sangat kekurangan dengan kata alsā'il dan al-mahrūm.

Al-Rāghib Al-Ișfahānīi, ${ }^{8}$ seorang ulama fikih dan tafsir, menyebutkan empat macam pengertian tentang fakir: (i) fakir dalam arti orang yang memerlukan kebutuhan hidup yang primer, yaitu makanan, minuman, tempat tinggal, dan keamanan; (ii) fakir dalam arti orang yang tidak dapat memenuhi kebutuhan hidupnya yang primer, tetapi ia dapat menjaga dirinya dari memintaminta; (iii) fakir dalam arti fakir jiwanya, ini termasuk golongan fakir yang paling buruk karena dapat mendorong orang kepada kekafiran; dan (iv) fakir dalam arti orang yang selalu merasa butuh kepada petunjuk dan bimbingan Tuhan, sehingga orang tersebut tidak merasa sombong. Yusuf Qardawi ${ }^{9}$ memberikan pengertian miskin dengan orang yang mempunyai harta atau penghasilan layak dalam memenuhi keperluannya: sandang, pangan, tempat tinggal dan segala keperluan pokok lainnya, baik untuk diri sendiri ataupun bagi mereka yang menjadi tanggungannya. Sedangkan pengertian al-sā'il dan al-mahrūm dalam berbagai kitab tafsir didefinisikan dengan orang miskin yang meminta-minta (al$s \bar{a} ' i l)$, dan kata al-mahrūm adalah orang miskin yang tidak memiliki harta, tetapi ia tidak meminta-minta sehingga tidak diketahui di mana ia berada.

Berdasarkan pengertian di atas, terlihat bahwa fakir, miskin, $a l-s \bar{a}$ ' $i l$ dan al-mahrūm adalah orang yang memiliki harta setengah dari kebutuhan hidupnya atau lebih tetapi tidak mencukupi kebutuhan hidupnya, baik untuk memenuhi kebutuhan dirinya atau tanggungannya, melalui jalan memintaminta ataupun tidak. 
Dalam al-Qur'an dijumpai kata fakir diungkap sebanyak 12 kali dan kata miskin sebanyak 25 kali, 5 ayat masingmasing digunakan untuk pengertian yang bermacam-macam. Adapun yang terkait dengan zakat, dalam al-Qur'an terdapat dua kata yang menunjukkan arti zakat, yaitu kata zakah dan kata sadaqah. Zakat dari aspek bahasa berasal dari kata dasar (mașdar) zakā yang berarti berkah, tumbuh, bersih dan baik. ${ }^{10}$ Sesuatu itu zak $\bar{a}$, berarti tumbuh dan berkembang, dan seseorang itu $z a k \bar{a}$, berarti orang itu baik.

Sadaqah berasal dari kata șadaqa yang berarti lawan dari dusta atau pemberian. Karenanya sadaqah berarti apa yang diberikan karena Allah untuk orang-orang fakir dan miskin. Dan kata al-mutașaddiq berarti orang yang memberikan sadaqah. ${ }^{11}$ Penggunaan kata sadaqah yang berasal dari kata sadaqah dapat mengandung pengertian bahwa pemberian sadaqah itu terkait dengan kejujuran seseorang. Orang yang memberikan sadaqah adalah orang yang jujur, yang tidak berdusta dengan keimanannya sendiri. Karena itu sadaqah adalah bukti kebenaran iman sebagaimana halnya bakhil sebagai bukti kedustaan. Pengertian di atas sebagaimana ditegaskan dalam Q.S. AlLail (92) : 5-9.

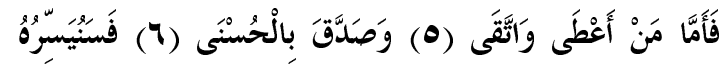

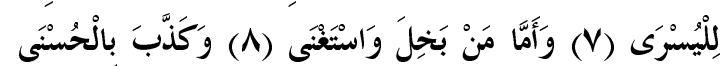

"Adapun orang yang memberikan (hartanya di jalan Allah) dan bertakwa. Dan membenarkan adanya pahala yang terbaik (syurga), maka Kami kelak akan menyiapkan baginya jalan yang mudah. dan Adapun orang-orang yang bakhil dan merasa dirinya cukup serta mendustakan pahala terbaik."

Zakat dari aspek istilah fikih didefinisikan oleh para ulama dengan definisi yang beragam. Yusuf Qardawi mendefinisikan zakat dengan "sejumlah harta tertentu yang diwajibkan Allah diserahkan kepada orang-orang yang berhak.“12 Ulama Malikiyyah memberikan pengertian zakat dengan "pengeluaran bagian tertentu dari harta tertentu yang telah mencapai nisab untuk mustahiknya jika telah sempurna kepemilikan dan hawl kecuali barang tambang dan pertanian yang tidak ada hawl-nya". Ulama Hanafiyyah mendefinisikan zakat dengan "menjadikan hak milik bagian harta tertentu dari harta tertentu untuk orang tertentu yang telah ditentukan oleh syar' $i$ karena Allah". Ulama Syafi'iyyah mendefinisikan zakat dengan "nama bagi sesuatu yang dikeluarkan dari harta atau badan atas jalan tertentu". Ulama Hanabilah memberikan pengertian zakat dengan "hak yang wajib dalam harta tertentu bagi kelompok tertentu pada waktu tertentu". ${ }^{13}$

Berpijak kepada beberapa pengertian para ulama di atas, maka sesungguhnya zakat merupakan pengeluaran sejumlah harta orang tertentu yang menjadi hak orang lain atau perpindahan kepemilikan terhadap harta zakat tersebut dari kelompok tertentu yang dalam hal ini adalah orang kaya kepada kelompok lain yang berhak menerima.

Dalam al-Qur'an, kata zakat diungkap dalam bentuk ma'rifah sejumlah tiga puluh kali, dua puluh tujuh kali disebutkan dalam satu ayat bersama shalat, dan hanya satu kali disebutkan dalam konteks yang sama dengan shalat tetapi tidak di dalam satu ayat, yaitu Q.S. al-Mu'minun (23): 2 dan 4. ${ }^{14}$ Ketiga puluh kali kata zakat disebutkan itu, delapan terdapat di dalam surat-surat yang turun di Mekkah dan selebihnya diturunkan di Madinah. ${ }^{15}$

\section{Hal-hal yang Memicu Terjadinya Kemiskinan.}

Hal yang memicu terjadinya kemiskinan menurut John Kennet Galbraith $^{16}$ antara lain disebabkan oleh 
sifat pemerintahan dan sistem ekonomi yang tidak efektif, tidak teratur, korup dan tidak mampu dalam melaksanakan pemerintahan. Soedjatmoko ${ }^{17}$ menilai faktor ketidakadilan tampak begitu sentral memicu kemiskinan. Kesempatan bagi rakyat kecil untuk memperbaiki hidupnya selalu terhambat, karena seolah-olah mereka dimarginalkan dan dikucilkan dari kebijakan-kebijakan pembangunan. Akibatnya mereka tidak dapat berbuat banyak. Di pihak lain kemiskinan dan kesengsaraan masyarakat bukan disebabkan ketaatan manusia, melainkan oleh lembagalembaga masyarakat yang mempersulit hidup mereka. ${ }^{18}$

Muhammad Yunus (peraih Nobel tahun 2006 dari Bagladesh) menilai bahwa kaum miskin tidak menciptakan kemiskinan. Institusi-institusi yang dibangun serta kebijakan yang dibuat yang menciptakan kemiskinan. Jika ingin mengatasi penyebab kemiskinan, maka harus mengubah sikap institusi-institusi tersebut. ${ }^{19}$ Lebih jauh, Muhammad Yunus $^{20}$ menilai bahwa kemiskinan tercipta karena membangun kerangka teoritis berdasarkan asumsi-asumsi yang merendahkan kapasitas manusia, dengan merancang konsep-konsep yang terlampau sempit (seperti konsep bisnis, kelayakan kredit, kewirausahaan, lapangan kerja) atau mengembangkan lembaga-lembaga yang belum matang (seperti lembaga-lembaga keuangan yang tidak mengikutsertakan kaum miskin). Kemiskinan disebabkan oleh kegagalan pada tataran konseptual, dan bukan kurangnya kapabilitas di pihak rakyat.

Dalam terminologi sosiologis, ada dua faktor utama mengapa orang menjadi miskin, yaitu: (i) kultural/natural; dan (ii) struktural/buatan. $^{21}$ Kultural adalah kemiskinan yang dipicu oleh lemahnya etos kerja, sikap hidup yang patalis, salah dalam memahami makna rizki, malas berusaha termasuk malas mengembangkan kemampuan diri serta terperangkap pada budaya miskin itu sendiri. Kemiskinan struktual, yakni kemiskinan yang terjadi karena struktur sosial yang ada membuat anggota dan kelompok masyarakat tidak menguasai sarana ekonomi dan fasilitas secara merata. Dalam istilah lain, kemiskinan struktural lahir dari adanya setting sosial yang individualistik, yakni ketika orang kaya dengan egonya acuh tak acuh terhadap keadaan sekitarnya. ${ }^{22}$

\section{Zakat dan Pengentasan Kemiskinan.}

Islam adalah agama yang memberikan rahmat kepada alam semesta. Oleh karena itu, Islam tidak meligitimasi dan merestui kemiskinan, akan tetapi ia, melalui ajarannya menganjurkan umatnya menjadi kaya dan menganggap kemiskinan sebagai musuh bersama yang harus diminimalisir. Sebab dampak negatif kemiskinan bukan hanya pada pelemahan akidah yang mengakibatkan kekufuran, tetapi juga berimplikasi pada aspek kemanusiaan. Lily Zakiyah Munir ${ }^{23}$ menganggap kemiskinan merupakan pelanggaran Hak Asasi Manusia (HAM), karena setiap orang pada dasarnya berhak untuk hidup layak dan sejahtera. Orang yang miskin terbatas dalam asupan gizi, tebatas dalam pendidikan, kesehatan serta terpinggirkan dari berbagai fasilitas dan sumber daya untuk berkembang secara wajar.

Untuk itu, harus diawali dengan cara mewujudkan tatanan ekonomi yang memungkinkan lahirnya sistem distribusi yang adil, mendorong lahirnya kepedulian dari orang berpunya (kaya) terhadap kaum fakir miskin, serta kesadaran untuk meningkatkan kualitas diri, etos kerja dan sikap optimisme terhadap perubahan kehidupan. ${ }^{24}$ Karenanya tidak ditemukan satu ayat pun dalam al-Qur' an atau satu hadis-pun yang memerintahkan umat Islam miskin. Melainkan perintah untuk menjadi kaya yang peduli dan mau menolong orang miskin. Q.S. al-Baqarah (2): 177, menyatakan: 


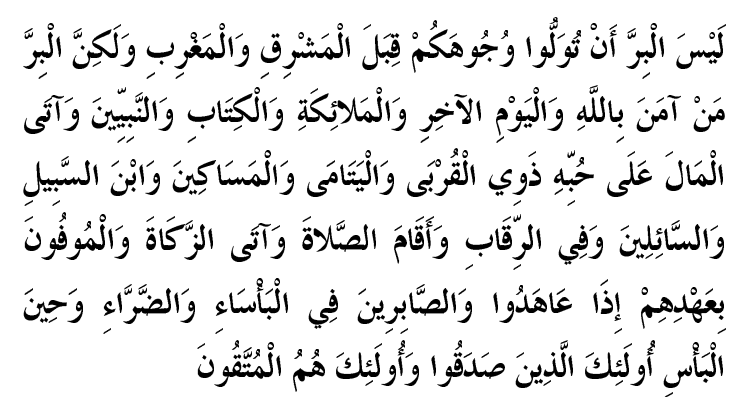

"Bukanlah menghadapkan wajahmu ke arah timur dan barat itu suatu kebajikan, akan tetapi sesungguhnya kebajikan itu ialah beriman kepada Allah, hari Kemudian, malaikat-malaikat, kitabkitab, nabi-nabi dan memberikan harta yang dicintainya kepada kerabatnya, anak-anak yatim, orang-orang miskin, musafir (yang memerlukan pertolongan) dan orang-orang yang meminta-minta; dan (memerdekakan) hamba sahaya, mendirikan shalat, dan menunaikan zakat; dan orang-orang yang menepati janjinya apabila ia berjanji, dan orangorang yang sabar dalam kesempitan, penderitaan dan dalam peperangan. Mereka itulah orang-orang yang benar (imannya); dan mereka itulah orangorang yang bertakwa."

Ayat di atas menegaskan bahwa, salah satu ciri orang takwa adalah kesediaannya membantu orang miskin agar dapat hidup lebih layak. A. Qodri Azizy ${ }^{25}$ menjelaskan bahwa Islam mengajarkan kepada umatnya untuk mengejar kesejahteraan di dunia dan di akhirat. Kesejahteraan akhirat orang yang beriman sudah sering mendapatkan pembahasannya. Sedangkan kebaikan dunia adalah tidak bisa lepas dari terwujudnya kualitas hidup yang meliputi kesejahteraan harta. Jelas sekali, miskin, terbelakang, bodoh, dan semacamnya tidaklah akan disebut baik atau berkualitas dalam hidupnya. Ini semua tidak menjadi cita-cita Islam secara doktrinal. Islam juga mengajarkan kepada umatnya untuk berupaya menyeimbangkan kesejahteraan antara dunia dan akherat. ${ }^{26}$
Yusuf Qardhawi, ${ }^{27}$ menyatakan dua konsep yang disalah artikan maknanya, sehingga seolah-olah Islam melarang orang menjadi kaya adalah zuhūd dan qan $\bar{a} a h$. Hadis-hadis yang memuji kehidupan zuhi $\bar{d}$ di dunia bukan berarti Islam memuji kemiskinan. Zuhüd bukan berarti menutup diri untuk memiliki sesuatu dalam kehidupan. Justru al-zahid ( orang yang zuhüd) sejati adalah orang yang memiliki dunia (harta kekayaan) namun dia memposisikan kekayaan tersebut dalam tangannya dan bukan dalam hatinya. Karenanya banyak ditemukan dalam al-Qur'an, ayat-ayat yang memberikan peringatan moral maupun aturan hukum untuk membantu yang miskin sehingga kebutuhan dasar baginya dapat dipenuhi sebagaimana mestinya. Ziaudin Ahmad ${ }^{28}$ menjelaskan terdapat sejumlah ayat dalam al-Qur'an menekankan kebaikan infak, yaitu pemberian sukarela untuk kesejahteraan orang miskin. Sebagai contoh, telah dinyatakan bahwa tidak ada perkara di mana manusia akan mencapai kesalehan kecuali jika ia dengan rela mengeluarkan kekayaannya dengan cara yang diatur oleh Tuhan untuk mereka yang tidak mampu dan orang miskin. Bagi mereka yang infak telah dijanjikan menjadi orang-orang pilihan yang memperoleh kenikmatan di surga. ${ }^{29}$ Selanjutnya Nabi juga senantiasa mengingatkan para pengikutnya bahwa sebuah masyarakat yang gagal memelihara kebutuhan kaum fakir miskin tidak dapat dipandang sebagai seorang muslim. Demikian pula, ia memberi peringatan kepada para pengikutnya apabila ada sesuatu tempat dimana seseorang masih kelaparan di malam hari, maka Tuhan akan meninggalkan mereka.

Pesan-pesan al-Qur'an untuk menolong kaum fakir miskin melalui sebuah sistem jaminan sosial (infak dan zakat), tidak hanya untuk pribadi-pribadi muslim, melainkan juga memerintahkan negara bertugas menghimpun infak dan zakat dari hasil pendapatan bagian 
masyarakat yang mampu diperuntukkan bagi tujuan-tujuan tertentu dalam rangka menolong kaum fakir miskin yang dapat dihitung secara jelas. Selanjutnya sistem jaminan sosial ini diatur di zaman Nabi Muhammad SAW., dan berfungsi secara efektif pada periode Islam pertama dan dalam beberapa waktu tertentu pada periode berikutnya. Dalam catatan sejarah, memperlihatkan bahwa terdapat beberapa contoh dalam periode ini di mana pada daerah-daerah tertentu tidak ditemukan seorang fakir miskin yang dipandang bisa memperoleh derma. ${ }^{30}$

Karena begitu pentingnya hajat hidup, para penguasa pada periode Islam yang pertama sangat menyadari tanggung jawab mereka terhadap pemenuhan kebutuhan dasar seluruh warga negara. Keempat khalifah pertama yang berkuasa memerintah negara-negara Islam setelah wafatnya Nabi SAW, telah menganggap pemenuhan kebutuhan sebagai salah satu tujuan dasar dari kebijaksanaan negara. Dalam periode khalifah pertama, Abu Bakar, ada segolongan penduduk yang telah menolak untuk membayarkan zakat dipandang sebagai sebuah tindakan pemberontakan yang menentang negara sehingga tindakan bersenjata dilakukan untuk melawan mereka sampai mereka sependapat untuk membayar zakat. Khalifah kedua, Umar, juga sangat menyadari tanggungjawab ini sehingga ia mengumumkan "Jika seekor unta mati tanpa perawatan di tepi sungat Eufrat, saya takut Allah akan meminta pertanggungjawaban saya terhadap hal itu".

Jadi, jelaslah bahwa zakat bukan hanya ibadah mahdah fardiyah (individual) kepada Allah untuk mengharmoniskan hubungan vertikal kepada Allah. Lebih dari itu, sebagai ibadah mu'àmalah ijtimā'iyyah (sosial) dalam rangka menjalin hubungan horizontal sesama manusia, dan salah satu intrumen distribusi kekayaan. Maka, zakat harus ditempatkan tidak hanya dalam konteks individual tapi sudah menjadi bagian dari persoalan komunal, dalam hal ini keterlibatan dan peran pemerintah. ${ }^{31}$

Penanganan zakat oleh pemerintah melalui suatu lembaga khusus yang memiliki sistem manajemen yang fungsional dan profesional seperti diisyaratkan dalam hadis Nabi SAW., menjadi mutlak adanya. Hal itu dimaksudkan untuk mencapai hasil yang optimal dan efektif. $^{32}$ Lebih jauh ia mengatakan, jika terjadi hambatan dalam pemungutan zakat dari tangan orang kaya, maka pemerintah dapat menetapkan sanksi pidana dan sejenisnya terhadap mereka yang membangkang membayar zakat. Bahkan al-Qurțubi ${ }^{33}$ ketika menafsirkan Q.S. al-Tawbah (9): 60 menyatakan bahwa lafadz al-'ämilina 'alayh $\bar{a}$ itu bermakna amil yaitu, orangorang yang ditugaskan/diutus oleh imam/pemerintah untuk mengambil, menuliskan, menghitung, mencatatkan zakat yang diambilnya dari para muzakki dan untuk kemudian mendayagunakannya kepada yang berhak menerimanya. Hal itu menunjukkan, bahwa zakat bukanlah tugas kewajiban perseorangan, melainkan tugas kenegaraan. Karenanya, pemerintah harus mengurus, mengawal, dan mengangkat para amil yang bertugas mengelola zakat.

Untuk mewujudkan sistem pengelolaan zakat yang komprehensif, maka regulasi, sinergi, tata kelembagaan, pengawasan dan sosialisasi yang berkesinambungan merupakan hal mendasar. Regulasi dan sinergi bisa dilakukan dengan cara membagi peran dan tugas sesuai dengan kewenangan masing-masing. Pemerintah, misalnya bertindak sebagai pembuat kebijakan dan pengawasan serta menjatuhkan sanksi kepada lembaga yang terbukti melakukan pelanggaran.

$$
\text { Sjechul Hadi Permono, }{ }^{34}
$$
berpendapat bahwa pengelolaan zakat itu merupakan tugas kenegaraan. Ia harus 
dikelola oleh pemerintah yang sah menurut pandangan Islam. Ia berkewajiban membentuk badan amil zakat. Zakat harus diserahkan kepada dan harus diurus oleh badan itu. Pemerintah berkewajiban untuk memaksa untuk dipatuhinya kewajiban membayar zakat. Pemerintah tidak boleh membiarkan para pemilik harta benda berjalan sendirisendiri untuk menyelesaikan urusan zakatnya.

Zakat sebagai salah satu cara untuk mengatasi kemiskinan atau pemecahan masalah ekonomi umat, juga memiliki fungsi yang sangat strategis dalam konteks sistem ekonomi, karena zakat sangat efektif dan memiliki keunggulan bila dibandingkan dengan institusi fiskal yang telah ada dewasa ini. Keunggulan zakat tersebut antara lain; Pertama, penggunaan dana zakat sudah ditentukan secara jelas dalam syariat ${ }^{35}$ di mana zakat hanya diperuntukkan bagi 8 golongan saja (asnaf) yaitu orang-orang fakir, miskin, amil zakat, mu allaf, budak, orang yang berhutang, jih $\bar{a} d f \bar{i}$ sabilillah dan ibnu al-sabîl. Jumhur ulama sepakat bahwa selain 8 așnäf tersebut, tidak halal menerima zakat. Karakteristik ini membuat zakat secara inheren bersifat pro poor. Tidak ada satu pun instrumen fiskal konvensional memiliki karakteristik unik seperti ini. Kedua, zakat memiliki tarif yang tetap karena sudah diatur dalam syariat, sebagai misal, zakat yang diterapkan pada basis yang sangat luas seperti zakat māl tarifnya hanya $2,5 \%$. Begitu juga tarif zakat terhadap harta lainnya ada yang 5 $\%$ dan ada yang $10 \%$. Karena itu penerapan zakat tidak akan mengganggu insentif investasi dan akan menciptakan transparansi kebijakan publik serta memberikan kepastian usaha. Ketiga, zakat dikenakan pada basis yang sangat luas meliputi berbagai aspek perekonomian yang sangat luas, bahkan fikih kontemporer memandang bahwa zakat juga diambil dari seluruh pendapatan yang dihasilkan dari asset atau keahlian bekerja. Dengan demikian, potensi zakat menjadi semakin besar. Hal ini menjadi modal dasar yang penting bagi pembiayaan program-program pengentasan kemiskinan.

Yusuf Qardhawi, membagi tujuan zakat ke dalam tiga bagian: (i) muzakk $\bar{i}$ (pihak wajib zakat); (ii) mustahiq alzakah (pihak penerima zakat); dan (iii) kepentingan masyarakat (sosial). ${ }^{36}$ Bagi pihak wajib zakat, tujuannya antara lain, untuk menyucikan dari sifat bakhil, rakus, egoistis, melatih jiwa untuk bersikap terpuji, menumbuhkan sikap kasih sayang kepada sesama, membersihkan nilai harta dari unsur noda, melatih diri agar menjadi pemurah, serta menumbuhkembangkan harta itu sehingga memberi keberkatan bagi pemiliknya. Kemudian, bagi pihak penerima zakat, antara lain, untuk memenuhi kebutuhan hidup, tersucikannya hati mereka dari rasa dengki dan kebencian yang sering menyelimuti hati mereka melihat orang kaya yang bakhil, memunculkan rasa simpatik, hormat serta rasa tanggung jawab untuk ikut mengamankan dan mendoakan harta orang-orang kaya yang pemurah. Sedangkan tujuan zakat bagi kepentingan masyarakat, antara lain adalah bahwa zakat bernilai ekonomik, merealisasi fungsi harta sebagai alat perjuangan menegakkan agama Allah, dan mewujudkan keadilan sosial ekonomi masyarakat pada umumnya. ${ }^{37}$ Dengan demikian, jelas bahwa zakat mempunyai dimensi sosial disamping dimensi sakral sehingga apabila tidak ditunaikan akan menimbulkan dampak negatif berupa kerawanan sosial, seperti banyaknya pengangguran dan masalah-masalah sosial lainnya. ${ }^{38}$

Karena zakat, yang sifatnya ilzami ijbara $\bar{i}$ (kewajiban mutlak) yang harus dilaksanakan dengan pasti dan merupakan sumber dana potensial untuk dimanfaatkan bagi pembangunan bangsa dan ketahanan negara dalam mengentaskan kemiskinan dan 
menghilangkan kesenjangan sosial, perlu adanya pengelolaan zakat secara profesional dan bertanggung jawab. Karenanya badan amil zakat sebagai administrator dan manajemen zakat, mempunyai tugas sebagai pemungut (kolektor), penyalur (distributor), pengorganisasian, motivator, pengawas dan evaluasi. Hal ini dimaksudkan untuk mencapai hasil yang optimal dan efektif. Untuk mengantisipasi terjadinya hambatan dalam pemungutan zakat dari orang-orang kaya, maka pemerintah dapat menetapkan sanksi pidana dan sejenisnya terhadap mereka yang membangkang tidak mau mengeluarkan zakatnya.

Pengelolaan zakat oleh pemerintah adalah logis, karena beberapa pertimbangan; pertama, untuk menjamin kepastian dan disiplin pembayar zakat. Kedua, menjaga perasaan rendah diri orang yang berhak menerima zakat apabila berhadapan langsung menerima haknya dari para wajib zakat (muzakkī). Ketiga, untuk mencapai efisiensi, efektifitas dan sasaran yang tepat dalam penggunaan harta zakat menurut skala prioritas yang ada pada suatu tempat. Keempat, untuk memperlihatkan syiar Islam dalam semangat penyelenggaraan negara dan jika pelaksanaan zakat langsung diserahkan kepada setiap wajib zakat (muzakkî), maka nasib dan hak-hak orang-orang miskin dan orang-orang kaya tidak memperoleh jaminan yang pasti. Azas operasionalisasi dan pelaksanaan zakat itu tentunya tidak mengabaikan sifat dan kedudukan zakat itu sendiri sebagai ibadah mahdah yang bersifat ilzāmî ijbārì.

Di Indonesia, setelah lahirnya UU No. 38 tahun 1999 tentang Pengelolaan Zakat dan UU No.17 tahun 2000 tentang Pajak, pengelola zakat adalah Badan Amil Zakat (BAZ) yang dibentuk oleh pemerintah, baik di tingkat pusat maupun di tingkat daerah. BAZ ini terdiri dari unsur masyarakat dan pemerintah yang memenuhi persyaratan tertentu, antara lain memiliki sifat amanah, adil, berdedikasi, profesional dan mepunyai integritas. Di lain pihak, masyarakat tetap diberikan kesempatan untuk mendirikan institusi pengelolaan lembaga zakat yang sepenuhnya dibentuk atas prakarsa dan oleh masyarakat sendiri yang disebut Lembaga Amil Zakat (LAZ). Pasal 9 huruf g UU No. 17 tahun 2000 tentang pajak menyebutkan bahwa zakat bukan merupakan objek pajak bagi penerima, dan zakat atas penghasilan boleh dikurangkan dari penghasilan kena pajak.

Jika isi Undang-undang tersebut ditelaah, tampaknya pemerintah Indonesia mulai ikut terlibat dalam pengelolaan dan pengurusan zakat, sekalipun keterlibatan pemerintah tidak penuh dan tidak kuat. Indikatorindikatornya dapat dilihat pada: (i) pembentukan Amil Zakat; (ii) pembinaan dan perlindungan yang harus diberikannya kepada Badan Amil Zakat dan Lembaga Amil Zakat; (iii) menerima pertanggung jawaban BAZ dan LAZ; (iv) menempatkan sebagian aparaturnya dalam kepengurusan zakat; dan (v) membantu biaya operasional BAZ.

Keterlibatan pemerintah dalam pengaturan dan pengelolaan zakat seperti yang terlihat di atas mengindikasikan telah terjadinya peningkatan keterlibatan negara dalam pelaksanaan zakat di Indonesia. Meskipun ketika lahir undangundang tersebut banyak pula pihak-pihak yang masih berkeberatan dengan keterlibatan pemerintah dalam pengurusan zakat. Lagi-lagi argumen yang sering dimunculkan adalah Indonesia bukan negara Islam. ${ }^{39}$

Potensi zakat umat Islam Indonesia, sesungguhnya adalah potensi dana umat yang sangat luar biasa. Para pakar dan praktisi pengelola zakat memprediksi potensi zakat umat Islam di Indonesia mencapai 10 triliun. Perhitungan yang telah dilakukan hanya sebatas pada perhitungan potensi minimal. Menurut Said Agil al- 
Munawwar (mantan Menteri Agama RI ) potensi zakat umat Islam di Indonesia mencapai 7,5 triliun rupiah per tahun. Abu Syauki (Direktur Rumah Zakat DSUQ) berdasarkan data tahun 2004 potensi zakat umat Islam di Indonesia mencapai 9 triliuun rupiah. Dewan Syariah Dompet Dhuafa memprediksi 5,1 triliun, sedangkan hasil survey yang pernah dilakukan oleh Pusat Bahasa dan Budaya (PBB) UIN Syarif Hidayatullah Jakarta selama tahun 2004 menunjukkan angka yang sangat fantastik yakni potensi dana zakat, infaq dan shadaqah (ZIS) umat Islam di Indonesia mencapai angka 19, 3 Trilyun.

Namun demikian, hasil penelitian dari LSM PIRAC sekitar tahun 2001 2002, potensi dana zakat yang besar itu, hanya mampu diserap oleh masyarakat sekitar 53,3\% dari total potensi yang ada dan ironisnya hanya 3,3\% yang mampu dikumpulkan oleh Lembaga Pengelola Zakat (LPZ). Hal ini menunjukkan realisasi pengumpulan zakat masih jauh dari potensi yang ada. Bahkan, hingga 2009 baru Rp. 1,2 triliun yang berhasil dihimpun oleh lembaga-lembaga pengelola zakat. ${ }^{40} \mathrm{Hal}$ ini menunjukkan realisasi pengumpulan zakat masih jauh dari potensi yang ada.

Untuk kasus penghimpunan zakat di Indonesia, sesungguhnya dana zakat yang terkumpul sangat besar apabila dibandingkan dengan APBN 2004, potensi di atas sungguh sangat bermakna. Pembiayaan untuk pembangunan pada sub sektor kesejahteraan sosial hanya sebesar Rp. 1,7 triliun rupiah, dan sub sektor kesehatan sebesar Rp. 5,3 triliun rupiah. Artinya, dengan potensi zakat penghasilan yang nilainya sekitar Rp 12,3 triliun rupiah itu, banyak hal dapat dilakukan asalkan masih dalam koridor delapan golongan yang berhak menerima dana zakat.

Data di atas akan semakin besar apabila ditambah dengan potensi zakat pertanian, perkebunan, kehutanan, harta terpendam, barang tambang (termasuk minyak bumi, gas alam, tambang emas, perak), kekayaan laut, peternakan, harta emas/perak, harta simpanan, perdagangan, saham, obligasi, investasi industri dan zakat fitrah serta infak, shadaqah, kafarat, fidyah, waris, wakaf dan lain-lainnya.

Zakat dikelola oleh BAZ dan LAZ, menurut Fuad Zein ${ }^{41}$ berimplikasi yuridis, finansial, moral, praktikal, dan jaringan. Implikasi yuridis, artinya BAZ dan LAZ sebagai institusi publik yang mengelola dana publik, memiliki legalisasi hukum dalam bentuk UU No.38 tahun 1999 tentang Pengelolaan Zakat. Implikasi finansial, zakat berpotensi menjadi dana masyarakat yang sangat besar dan tidak lagi dipandang sebagai kegiatan karitatif di luar sistem hukum dan institusi negara. Implikasi moral, potensi zakat yang besar menggembirakan terutama dalam pengentasan kemiskinan. Tetapi juga mengandung "kerawanan" dan ladang korupsi baru, bila tidak disikapi dengan pengelola yang amanah, transparan, akuntabilitas publik, profesional, dan pengawasan. Implikasi praktis, berhasil tidaknya Lembaga Pengumpul Zakat (LPZ) dalam mengelola dana zakat sangat bergantung pada SDM sesuai kaedah-kaedah manajemen yang benar. Sedangkan implikasi jaringan, bermunculannya LPZ-LPZ yang banyak pada satu sisi sangat menguntungkan, di sisi lain terjadinya overlaping baik penghimpunan maupun penyalurannya, maka diperlukan membangun jaringan untuk mengatasi ketiadaan koordinasi, komunikasi dan informasi diantara LPZ yang ada.

\section{E. Penutup}

Dari berbagai uraian dan pemaparan di atas, paling tidak terdapat beberapa hal yang dapat disimpulkan:

1. Syari'at Islam memiliki banyak hukum yang berkaitan dengan pemecahan masalah kemiskinan, baik kemiskinan kultural, maupun 
sruktural. Hanya saja, hukum-hukum itu tidak berdiri sendiri, melainkan memiliki hubungan sinergis dengan hukum-hukum lainnya. Jadi, dalam menyelesaikan setiap masalah, termasuk kemiskinan, Islam menggunakan pendekatan yang bersifat terpadu.

2. Zakat yang bersifat ilzāmi ijbāri tidak bisa hanya dipahami dalam paradigma ibadah fardiyyah untuk mengharmoniskan hubungan vertikal kepada Allah semata, tetapi ia juga merupakan ibadah mu'ämalah ijtimāiyyah yang memiliki dimensi ekonomi, sosial dan politik.

3. Campur tangan pemerintah dalam pengelolaan zakat merupakan keharusan. Karenanya keberadaan UU No. 38 tahun 1999 tentang Pengelolaan Zakat di Indonesia, perlu dilakukan amandemen, agar BAZ dan LAZ mempuyai kekuatan hukum yang kokoh dalam menarik harta muzakki. Wallahu a'lam bi alShawab.

\section{Catatan Akhir}

1 Republika, Kamis 13 Januari 2011, hlm. 2. Berdasarkan Data Badan Pusat Statistik (BPS), bahwa masyarakat miskin di Indonesia tahun 2010 berjumlah 31 juta $(13,33 \%)$ dari penduduk Indonesia.

${ }^{2}$ Hamdar Arraiyyah, Meneropong Fenomena kemiskinan: Telaah Perspektif alQur'an (Yogyakarta: Pustaka Pelajar, 2007), hlm. 1.

${ }^{3}$ Muhammad Ja'far Hafsah, Pengentasan kemiskinan Melalui Pemberdayaan Masyarakat (Bandung: Iris Press, 2008), hlm. 9.

${ }^{4}$ Didin Hafidhuddin, "Zakat sebagai Tiang Utama Ekonomi Syari'ah", makalah pada Seminar Bulanan MES, Aula BANK Mandiri Tower, 20 Nopember 2006.

${ }^{5}$ Lily Zakiah Munir, "Pesantren dan Strategi Pengentasan Kemiskinan" dalam alWashathiyyah, Vol. III N0. 14, 2008, hlm. 4-5.

${ }^{6}$ Fuad Zen, "Kontribusi Zakat bagi Kesejahteraan Masyarakat dan Permasalahannya: Sebuah Tilikan Normatif dan Empirik" dalam Antologi Pemikiran Hukum Islam di Indonesia: antara Idealitas dan Realitas (Yogyakarta:
Fakultas Syari'ah UIN Sunan Kalijaga Yogyakarta, 2008), hlm.13.

7 Anonim, Kamus Besar Bahasa Indonesia, cet. 7 (Jakarta: Balai Pustaka, 1996), hlm. 273 dan 660.

${ }^{8}$ Al-Rāghib al-Ișfahānī, Mu’jam Mufradāt Alfāz al-Qur'ān (Beirut: Dār al-Fikr, t.t.), hlm. 397-398.

${ }^{9}$ Lihat Yusuf Qardhawi, Hukum Zakat, terj. Salman Harun dkk., cet. 11 (Bogor: Pustaka Litera Antar Nusa, 2010), hlm. 512.

10 Majma' al-Lughah al-'Arabiyah, Mu'jam al-Wasit (Teheran: Maktabah alIlmiyyah, t.t), I: 398.

${ }^{11}$ Ibn Manzūr, Lisān al- 'Arab (Beirut:

Dār Ṣādir, t.t.), X: 193.

${ }^{12}$ Yusuf Qardhawi, Fiqh al-Zakāh, cet. 2 (Beirut: Muassasat ar-Risālah, 1973), hlm. 34.

${ }^{13}$ Wahbah al-Zuhayli, al-Fiqh al-Islāmî wa Adillatuh, cet.3 (Damaskus: Dār al-Fikr, 1989), II: 730-731.

${ }^{14}$ Q.S. al-Mu'minun (23) : 2 dan 4:

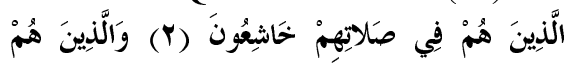

$$
\text { (飞) لِلزَّكَاةِ فَاعِلُونَ }
$$

${ }^{15}$ Muhammad Fu’ād 'Abd al-Bāqīi, Mu'jam al-Mufahras li Alfāz al-Qur'ān (ttp.: tnp., t.t.) pada kata "Zakat".

${ }^{16}$ John Kennet Galbraith, Hakekat Kemiskinan Massa (Jakarta: Penerbit Sinar Harapan, 1983), hlm. 11.

${ }^{17}$ Soedjatmoko, Dimensi Manusia dalam Pembangunan (Jakarta: LP3ES, 1983), hlm. 157.

${ }^{18}$ M. Dawam Raharjo, Esei-Esei Ekonomi Politik (Jakarta: LP3ES, 1983), hlm. 2 .

19 Lihat Wawancara dengan Muhammad Yunus dalam Al-Washathiyyah, Vol. III, No. 14, 2008, hlm. 58.

${ }^{20}$ Muhammad Yunus, Bank Kaum Miskin: Kisah Yunus dan Grameen Bank Memerangi Kemiskinan, terj. Irfan Maulana (ttp.: tnp., 2007), hlm. 274.

${ }^{21}$ Ismail Yusanto, “ Zakat dan Pendidikan Ekonomi Islam" dalam Problematika Zakat Kontemporer: Aktualisasi Proses Sosial Politik Bangsa (Jakarta: Forum Zakat, 2003), hlm. 120-122. Lihat pula Soetrisno, Memberdayakan masyarakat Pedesaan (Sidoarjo: Lembaga Ekonomi Budaya, 2001), hlm. 21.

${ }^{22}$ Ibid., hlm. 123.

${ }^{23}$ Munir, Pesantren dan Strategi, hlm.

6.

${ }^{24}$ Zen, Kontribusi Zakat, hlm. 14.

${ }^{25}$ A. Qodry Azizy, Membangun Fondasi Ekonomi Umat: Meneropong Prospek Berkembangnya Ekonomi Islam (Yogyakarta: Pustaka Pelajar, 2004), hlm. 4. 
${ }^{26}$ Lihat Q.S. Al-Qasas (28): 77.

${ }^{27}$ Qardhawi, Fiqh al-Zakah, hlm. 101.

${ }^{28}$ Ziauddin Ahmad, al-Qur'an: Kemiskinan dan Pemerataan Pendapatan, terj. Ratri Pirianita (Yogyakarta: Dana Bhakti Prima Yasa, 1998), hlm. 3-5.

${ }^{29}$ Lihat dalam Muhammad Husaen Haekal, The Life of Muhammad (ttp.: North American Trust Publications, 1976), hlm. 185187.

30،Abd al-"Azĩz Sayyid al-Ahl, AlKhaliffah al-Zahid 'Umar ibn 'Abd al-'Azīz (Beirut: Dār al-'Ilm li al-Malāyīn, 1973), hlm. 222.

${ }^{31}$ Di antara Hadits yang menjelaskan bahwa pemungutan zakat adalah hak negara (pemerintah) adalah hadits Mu'az bin Jabal ketika Rasulullah mengutusnya ke Yaman: diriwayatkan dari Ibn 'Abbas bahwa Nabi Saw berkata kepada Mu'az ketika diutus ke Yaman, “... apabila mereka patuh kepadamu untuk (berikrar dua kalimat syahadat) maka beritahukan kepada mereka bahwa Allah mewajibkan zakat kepada mereka pada harta benda mereka, diambil dari orang kaya di antara mereka, lalu dikembalikan kepada yang fakir di antara mereka. Lihat Al-Bukhārỉ, Sahỉh alBukhārī, cet.2 (Mesir: al-Sya'bỉ, t.t), hlm. 120.

32 Qardhawi, Musykilah al-Faqr wa Kayfa 'alajahā al-Islām, cet. 2 (Mesir: Maktabah al-Wahbah, 1975), hlm. 85.

${ }^{33} \mathrm{Al}-\mathrm{Qurțubì,}$ al-Jāmi' li Aḥkām alQur'ān (Libanon: Dār al-Kutub 'Ilmiyah, 1993), IV: 112-113.

${ }^{34}$ Sjechul Hadi Permono, Pemerintah Republik Indonesia Sebagai Pengelola Zakat, (Jakarta: Pustaka Firdaus, 1992), hlm. 154.

${ }^{35}$ Lihat Q.S. Al-Taubat (9) : 60.

${ }^{36}$ Qardhawi, Fiqh al-Zakah,, hlm. 108-

109.

${ }^{37}$ Zen, "Kontribusi Zakat," hlm.17-

18.

38 Abdurrachman Qadir, Zakat dalam Dimensi Mahdhah dan Sosial, cet. 2 (Jakarta: PT Raja Grafindo Persada, 2001), hal. 78.

${ }^{39}$ A. A. Miftah, Zakat Sebagai Hukum Diyani dan Qada'i dalam Negara Indonesia (Jakarta: PPs UIN Syarif Hidayatullah, 2005), hlm. 7.

${ }^{40}$ Didin Hafidhuddin, Makalah dalam Word Zakat Forum, Yogyakarta, 29-2 Oktober 20-10, hlm. 4.

${ }^{41}$ Zen, "Kontribusi Zakat," hlm. 21-23.

\section{DAFTAR PUSTAKA}

Al-Ahl, 'Abd al-Āzīz Sayyid. al-Khalifah al-Zahid Umar ibn 'Abd al-Aziz.. Beirut: Dar al-Ilm li al-Malayin, 1973.

Arraiyyah, Hamdar. Meneropong Fenomena Kemiskinan; Telaah Persfektif al-Qur'an. Yogyakarta: Pustaka Pelajar, 2007.

Azizy, A. Qodry. Membangun Fondasi Ekonomi Umat: Meneropong Prospek Berkembangnya Ekonomi Islam. Yogyakarta: Pustaka Pelajar, 2004.

Baqi, Muhammad Fuad Abdul. Mu'jam al-Mufahras li Alfadz al-Quran. Ttp: tnp., t.t.

Galbraith, John Kennet. Hakekat Kemiskinan Massa. Jakarta: Penerbit Sinar Harapan, 1983.

Haekal, Muhammad Husaen. The Life of Muhammad. New York: North American Trust Publications, 1976.

Hafidhuddin, Didin. "Zakat sebagai Tiang Utama Ekonomi Syari'ah" makalah pada Seminar Bulanan MES, 20 Nopember 2006.

Hafidhuddin, Didin. Agar Harta Berkah dan Bertambah. Jakarta: Gema Insani Press, 2007.

Hafsah, Muhammad Ja'far. Pengentasan Kemiskinan

Melalui

Pemberdayaan Masyarakat.

Bandung: Iris Press, 2008.

Ibn Manzur. Lisan al-'Arab. Beirut: Dār Șādir, t.t.

Majma' al-Lughah al-'Arabiyyah. Mu'jam al-Wasit. Teheran: Maktabah al-Ilmiyyah, t.t.

Miftah, A. A. Zakat Sebagai Hukum Diyani dan Qada'i dalam Negara Indonesia. Jakarta: PPs UIN Syarif Hidayatullah, 2005.

Permono, Sjechul Hadi. Pemerintah Republik Indonesia Sebagai Pengelola Zakat. Jakarta: Pustaka Firdaus, 1992. 
Qadir, Abdurrachman. Zakat dalam Dimensi Mahdhah dan Sosial, cet. 2. Jakarta: PT Raja Grafindo Persada, 2001.

Al-Qardhawi, Yusuf . Fiqh al-Zakah. Beirut: Dar al-Fikr, 1973.

- Hukum Zakat, terj. Salman Harun dkk. Bogor: Pustaka Litera Antar Nusa, 2010.

- Musykilah al-Faqr wa Kayfa 'Alajaha al-Islam. Mesir: Maktabah wahbah, 1975.

Al-Qurțubì. al-Jāmi' li Ạ̣kām al-Qur'ān. Lebanon: Dār al-Kutub al'Ilmiyyah, 1993.

Raharjo, M. Dawam. Esei-Esei Ekonomi Politik. Jakarta: LP3ES, 1983.
Yunus, Muhammad. Bank Kaum Miskin: Kisah Yunus dan Grameen Bank Memerangi Kemiskinan, terj. Irfan Maulana. Ttp: tnp., 2007.

Zen, Fuad. Antologi Pemikiran Hukum Islam di Indonesia Antara Idealitas dan Realitas, Yogyakarta: Fakultas Syari'ah UIN Sunan Kalijaga Yogyakarta, 2008.

Ziauddin, Ahmad. Al-Quran Kemiskinan dan Pemerataan Pendapatan, terj. Ratri Pirianita. Yogyakarta: Dana Bhakti Prima Yasa, 1998.

Al-Zuhayli, Wahbah. Al-Fiqh al-Islämī wa Adillatuh. Damaskus: Dar alFikr, 1989. 


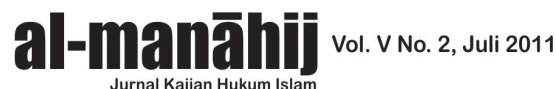

